\title{
Back to Work with Small Children Comparative Analyses of Maternity/Paternity Leave in the Member States of the European Union
}

\section{PhD Simona Maria Stanescu}

\author{
Research Institute for Quality of Life, Romanian Academy \\ simonastanescu2014@gmail.com
}

\section{Doi:10.5901/mjss.2015.v6n2s5p363}

\begin{abstract}
The paper contributes to the debate on how to increase fertility. The design of maternity/paternity leave in the 28 member states of the European Union (EU) is researched by secondary analyses on Eurostat and MISSOC databases. Results are presented by three categories of member states: EU founders, other old member states, and Central and East European (CEE) countries. The first part of the article overviews 1960-2012 demographic trends. The second part compares maternity/paternity leave as regulations, applicable statutory basis, basic principles and qualification conditions for benefits in kind and cash benefits, and the duration. 2012 EU-28 confronted the second highest values of deaths recorded for the period 1960-2012 while EU-28 births scored the lowest value since 2006. Updates for maternity/paternity leave date since 2000 in 24 out of EU28. Five member states follow pre-accession regulations. Legislation focuses specifically on maternity/paternity leave was adopted in 14 member states. Affiliation to compulsory social insurance scheme is the basic principle in providing benefits in kind and cash benefits. Half of member states do not request qualifying conditions for benefits in kind while six don't request any conditions for cash benefits. As duration, the pre-natal maternity leave implies either a precise period of time; either the total leave is to be shared with the post-natal periods. Pre-natal parental leave is regulated in only one country (Estonia); while post-natal is available in 21 member states. Maternity/paternity leave in the case of adoption is regulated in 21 EU member states.
\end{abstract}

Keywords: EU-28, population change, demographic drivers, fertility rate, maternity/paternity leave, benefits in kind, cash benefits

\section{Introduction}

Harmonisation of acquis communautaire in the social field within adherence to EU process by each candidate country, and further engagement towards achieving common targets (Europe 2020) question the post-accession development of national frameworks. On one hand, the European social model is challenged by newly entered member states, and one the other hand, the EU accession shape their social policy design (Vaughan-Whitehead, 2004, 496-501; Vonica, Radutiu 2004: 55-56, Stănescu, 2006, 101-102; Kvist, Saari, 2007, 246-248; Uzlau et al, 2009, 26-29; Cerami et al, 2009, 124126; Stănescu, 2013, 173-177, Stănescu, 2014, 191-192). From this perspective, the article offer a comparable comprehensive picture of provision of maternity/paternity leave as strategic elements in supporting EU-28 fertility.

The "Incomplete revolution" draws attention to the way public institutions respond to the new role of women in society (Esping-Andersen, 2009). Current family is challenged by demographic trends (Rotaru, 2009, 102-107; Popescu, 2009, 177-181; Ghetau, 2012, 56-58); postponement of marriages and children (Kuronen, 2010, 9; Muresan, 2014, 147148), precarious work and unemployment especially for women from vulnerable groups (Preoteasa, 2013, 165-166; Balan et al, 2014, 17-18; Vlase, 2014, 253-255), family conflicts (Turliuc et al, 2013, 42-46), the quality of community life (Mihalache, 2011, 138-139), migration (Balan et al, 2013, 78); provision of cash benefits and social services and the orientation of family support policies (Stanescu, 2014, 779-782). The degree of appropriateness answer to needs in taking care of the children have a direct consequence on children as they risk to be neglected or abused, to drop out school or to become delinquent (Neamtu, 2007, 212-233; Cojocaru, 2009, 70; Panzaru et al, 2013, 33; Luca, 2014, 3741; Tomita, 2014, 83-84).

\section{Methodology}

The first part of the article analysis the demographic trends in the EU-28 member states for the period 1960-2012: number of births and death, population change, demographic drivers, and fertility rate (live births per women). The second part focuses on national regulations adopted in the EU-28 with respect to maternity/paternity leave as 
chronological development of national regulations, basic principles, types of benefits (in kind, cash); and duration of leave. The third part of the paper is focus on conclusions and further research directions.

In terms of methodology, secondary analysis and content analysis were used for Eurostat, the statistical office of the EU and the Mutual Information System on Social Protection (MISSOC) database of the European Commission, Directorate-General for Employment, Social Affairs, and Equal Opportunities. Desk research allows that national information was double checked and improved updates were added.

Compared EU-28 research outputs were presented in relation to their accession to the EU by the following typology: the EU founder states ${ }^{1}$, other old member states than EU founders ${ }^{2}$, and Central and East European (CEE) member states ${ }^{3}$ (Stănescu, Nemtanu, 2015). The paper continues previous research done on EU member states and on family benefits as part of a post-doctoral programme as acknowledged.

\section{Demographic Trends}

According to Eurostat data for the period 1961-2012, the number of EU-28 births continues to decrease while the number of EU-28 deaths is slowly increasing.

The highest value of births was registered in 1964 with 7.81 millions while the lowest one was recorded in 2002 with 5. 03 millions. In 2012, the number of births was 5. 23 millions representing the lowest since 2006, and one of the lowest for the period 1961-2012.

The number of deaths scored the highest value in 1993 with 5. 03 millions, and the lowest one in 1961 with 4. 14 millions. Both in 2012, and in 1985, the second highest EU-28 value of deaths was registered: 5.01 millions.

The EU-28 natural change as the difference between live births, and number of deaths registered top three highest values during the 1960s: 3. 6 millions in 1964, 3. 5 millions in 1961, and 3. 3 millions in both 1963, and in 1965. Lowest values of natural change were recorded starting with the mid 1990s: 0.1 million in both 2002 and 2003; and 0. 2 millions for the period 1995-1999, for 2001, and for 2012.

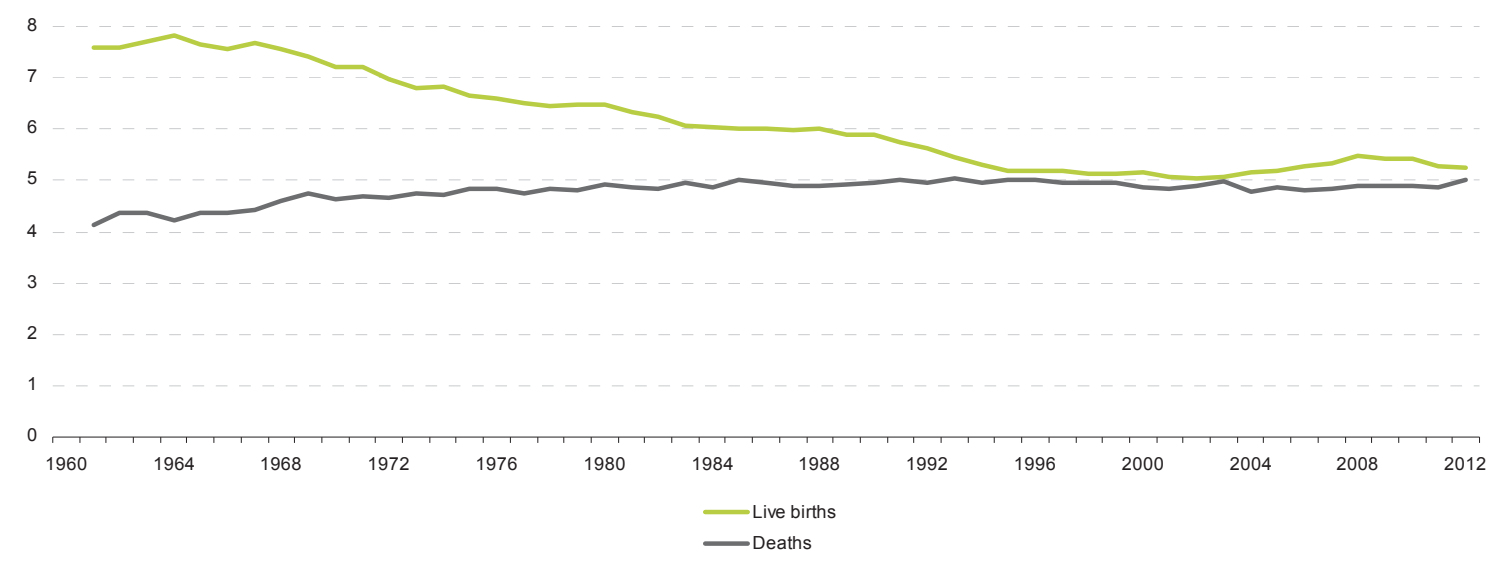

Figure 1: Births and deaths, EU-28, 1961-2012 (million)

Source: Eurostat

Note: 1960 not available. Excluding French overseas departments up to and including 1997

The EU-28 total population change for the period 1960-2012 registered the highest three values during the 1960s: in 1962 with 10. 16 per 1000 inhabitants; in 1964 with 8. 43; and in 1963 with 8. 35. Lowest values of total population change were recorded during the second half of the 1990s: in 1997 with 1. 39; in 1998 with 1. 44, and in 1996 with 1. 53.

Net migration and statistical adjustment as the total change minus natural change registered the highest EU-28 values during the 2000s: 3. 66 in 2003, 3. 41 in 2004, and 2. 63 in 2006. To the contrary, the lowest values were registered in 1970 (-1. 60), in $1982(-0.52)$, and in $1967(-0.49)$.

1 France, Germany, Italy, The Netherlands, Belgium, and Luxembourg

2 Denmark, Ireland, United Kingdom, Greece, Portugal, Spain, Austria, Finland, and Sweden

${ }^{3}$ Cyprus, Czech Republic, Estonia, Hungary, Latvia, Lithuania, Malta, Poland, Slovakia, Slovenia; Bulgaria, Romania, and Croatia 


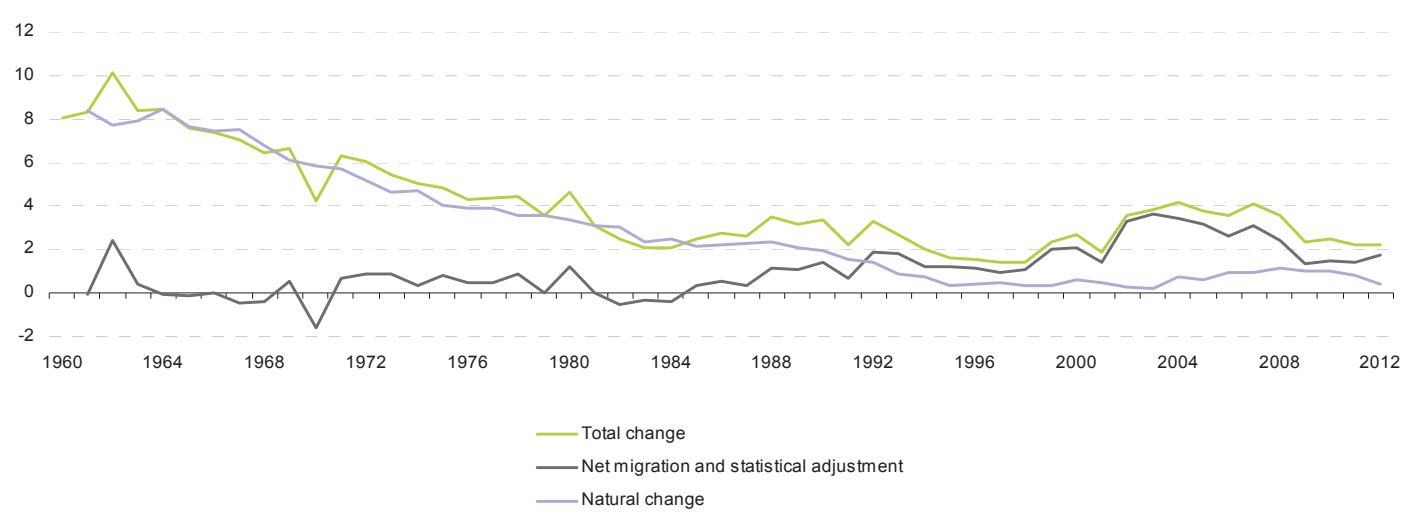

Figure 2: Population change by component (annual crude rates), EU-28, 1960-2012 (per 1000 inhabitants) Source: Eurostat

Note: 1960 not available for net migration, and statistical adjustment, and for natural change. Excluding French overseas departments up to and including 1997. Breaks in series: 2001, 2007 and 2011-12.

In respect to EU-28 population change between $1^{\text {st }}$ of January 2012 and 2013 by the three analysed categories of EU member states, demographic drivers led to growth. It was the case of all six EU founder states; five out of nine other old member states than the EU founders, and five out of 13 CEE member states. Growth due only to natural change was not registered in any EU founder states, but this was the case of Ireland and Cyprus. None of the CEE countries registered positive population change because the population growth was faced with the negative net migration (and adjustment).

No population decline was registered in the six EU founder states. In the case of other old member states, the population decline was not due to natural change but, similar to the new member-state, some of these states (Greece, Portugal, and Spain) recorded decline because of net migration (and adjustments), and to negative migrations (and adjustments).

Table 1: Contribution of natural change and net migration (and statistical adjustment) to population change, 2012

\begin{tabular}{|l|c|c|c|c|c|c|}
\hline & \multicolumn{3}{|c|}{ Population growth } & \multicolumn{3}{c|}{ Population decline } \\
\cline { 2 - 7 } & $\begin{array}{c}\mathrm{EU} \text { founder } \\
\text { states }\end{array}$ & $\begin{array}{c}\text { Other old } \\
\text { member states }\end{array}$ & $\begin{array}{c}\text { CEE member } \\
\text { states }\end{array}$ & $\begin{array}{c}\mathrm{EU} \\
\text { founder } \\
\text { states }\end{array}$ & $\begin{array}{c}\text { Other old } \\
\text { member } \\
\text { states }\end{array}$ & $\begin{array}{c}\mathrm{CEE} \text { member } \\
\text { states }\end{array}$ \\
\hline Only to natural change & - & $\mathrm{E}$ & $\mathrm{CY}$ & - & - & $\mathrm{HU}, \mathrm{RO}$ \\
\hline More to natural change & $\mathrm{FR}, \mathrm{NL}$ & $\mathrm{UK}$ & $\mathrm{Sl}$ & - & - & $\mathrm{BG}, \mathrm{HR}$ \\
\hline More to net migration (and adjustment) & $\mathrm{BE}, \mathrm{LU}$ & $\mathrm{DK}, \mathrm{FI}, \mathrm{SW}$ & $\mathrm{CZ}, \mathrm{MT}, \mathrm{SK}$ & - & $\mathrm{EE}, \mathrm{PT}$ & $\mathrm{ET}, \mathrm{LV}, \mathrm{LT}$ \\
\hline Only to negative net migration (and adjustment) & $\mathrm{DE}, \mathrm{IT}$ & $\mathrm{AT}$ & - & - & $\mathrm{ES}$ & $\mathrm{PL}$ \\
\hline
\end{tabular}

\section{Source: Eurostat}

For the period 1960-2012, the highest values of fertility rates as live births per women developed different trends among the three categories of EU member states.

Top position for EU founder states was shared by two countries: The Netherlands and France.

The category of other old member states than EU founders was the most stable one with the same country occupying top position except for one year. Ireland had highest values of fertility rates except for 1990 when Sweden registered 2,13 (comparable with 2,11 in Ireland). It is to be mention that abortion is allowed in Ireland only to safe the life of the women. At EU-28 level, abortion restrictions in Ireland are surpassed only by Malta where even above mention ground is strictly forbidden.

The situation of fertility rates in the CEE member states is differentiated as six out of the 13 countries ranked on top positions. The highest values were registered three times in Estonia (2005, 2010, and 2011); twice in Slovakia (1960 and 1970); and once in Romania (1980); in Cyprus (1990); in Malta (2000); and in Lithuania (2012). It was noticed a slight difference in the case of Croatia which registered 1,50 in 2005 as compared with top 1,52 for Estonia. 
In terms of highest value per categories of countries, the EU founders members registered fertility rate of 3,12 in 1960 in the Netherlands, while other old member state had rates of as had 3,85 in 1970 in Ireland, and CEE registered fertility rates of registered 3,04 in 1960 in Slovakia. Looking at the highest value of fertility rates indicator, we notice that the lowest values registered per category of countries were: 1,78 (in 1990 in France as representative for the EU founder states category); 1,86 in 2005 in Ireland (for the category of other old member states); and 1,52 also in 2005 in Estonia (for the CEE member states).

Table 2: Highest values of fertility rates per categories of member states of the European Union

\begin{tabular}{|c|c|c|c|}
\hline & EU founder states & Other old member states & Central and Eastern member states \\
\hline 1960 & 3,12 Netherlands & 2,78 Ireland & 3,04 Slovakia \\
\hline 1970 & 2,57 Netherlands & 3,85 Ireland & 2,41 Slovakia \\
\hline 1980 & 1,95 France & 3,21 Ireland & 2,43 Romania \\
\hline 1990 & 1,78 France & 2,13 Sweden & 2,41 Cyprus \\
\hline 2000 & 1,89 France & 1,89 Ireland & 1,70 Malta \\
\hline 2005 & 1,94 France & 1,86 Ireland & 1,52 Estonia \\
\hline 2010 & 2,03 France & 2,05 Ireland & 1,72 Estonia \\
\hline 2011 & 2,01 France & 2.03 Ireland & 1,61 Estonia \\
\hline 2012 & 2,01 France & 2,01 Ireland & 1,60 Lithuania \\
\hline
\end{tabular}

Source: Eurostat

We analyse bellow the lowest values registered for the fertility rate looking at top ranked countries and their recorded values. Looking at the EU founder states, Luxembourg occupied this position three consecutive times (1960, 1970, and 1980), and than Italy follows for three times in this ranking (1990, 2000, and 2005). Starting with 2004, Germany is constantly the EU founder state with the lowest fertility rate.

Lowest fertility rates in other old member states than the EU founder states was recorded in two north countries (in 1970 in Finland and in 1980 in Denmark), followed by two south countries Greece (1960, 2005, and 2012); and Spain $(1990,2000,2010$, and 2011). The slight value difference can be noticed which was registered in Spain in respectively 1. 33, as compared with 1,32 in Greece.

Five out of the 13 CEE member states, registered lowest values of fertility rates: three times in Hungary (1980, 2000, and 2011); twice in the Czech Republic (1970 and 2000); twice in Poland (2005 and 2012); and once in Estonia (1960); and in Slovenia (1990). Estonia is the only country which was present in both top rankings: as the country with the lowest fertility rate in 1960 and the highest one in 2005, 2010, and 2011. An in-depth national analysis of the reasons behind this change is not the topic of the present paper but these findings could be further developed and could support the identifying process of best practices in the pro-fertility field that would have the potential to be adjusted for other EU national contexts.

Table 3: Lowest values of fertility rates per categories of member states of the European Union

\begin{tabular}{|c|c|c|c|}
\hline & EU founder states & Other old member states & Central and Eastern member states \\
\hline 1960 & 2,29 Luxembourg & 2,23 Greece & 1,98 Estonia \\
\hline 1970 & 1,97 Luxembourg & 1,83 Finland & 1,92 Czech Republic \\
\hline 1980 & 1,50 Luxembourg & 1,55 Denmark & 1,91 Hungary \\
\hline 1990 & 1,33 Italy & 1,36 Spain & 1,46 Slovenia \\
\hline 2000 & 1,26 Italy & 1,23 Spain & 1,15 Czech Republic \\
\hline \multirow{2}{*}{2005} & 1,34 Italy & 1,32 Greece & 1,24 Poland \\
\cline { 2 - 3 } & 1,34 Germany & 1,37 Spain & 1,25 Hungary \\
\hline 2010 & 1,39 Germany & 1,34 Spain & 1,26 Hungary \\
\hline 2011 & 1,36 Germany & 1,32 Spain & 1,30 Poland \\
\hline \multirow{2}{*}{2012} & 1,38 Germany & 1,34 Greece & \\
& & & \\
\hline
\end{tabular}

Source: Eurostat

Different statistic data are provided by Eurostat for Slovakia and for the Czech Republic before 1989. Still, while Slovakia 
held the top position in 1970, the Czech Republic registered the lowest values among CEE countries. The differences due to different regulations in supporting families are not approached in this paper but they could bring further insights in this matter.

\section{Chronological Development of Regulations of Maternity/Paternity Leave}

Recent updates in maternity/paternity leave in 24 analysed countries date since 2000. The four exceptions are: Austria with regulations from 1967; United Kingdom back in 1992; and Belgium and Hungary since 1997. The newest EU-28 legislative modifications were adopted by Bulgaria in 2014.

Among EU founder states, Belgium preserves its regulations since 1997 while latest changes were registered in 2012 in Germany and in Italy. In the case of France the modifications in maternity/paternity leave are impacted also by the Social Security Code which is regularly updated.

Table 4: Recent regulations of maternity/paternity leave within founder members of the European Union

\begin{tabular}{|c|c|c|c|}
\hline No. & Country & EU & Latest regulations \\
\hline 1. & France & 1951 & 2015 \\
\hline 2. & Germany & 1951 & 2012 \\
\hline 3. & Italy & 1951 & 2012 \\
\hline 4. & The Netherlands & 1951 & 2005 \\
\hline 5. & Belgium & 1951 & 1997 \\
\hline 6. & Luxembourg & 1951 & 2008 \\
\hline
\end{tabular}

\section{Source: MISSOC data base}

Within other old member states than EU founders, Austria is the only case where latest regulations date before its accession to the EU. The newest ones are in Denmark, since 2013, 30 years after becoming a member state. In comparison with the moment of joining the $\mathrm{EU}$, latest regulations date 32 years after EU accession in Ireland; 23 years after in both Spain and Portugal; 19 years after in United Kingdom and Greece; 15 years after in Sweden; and nine years in Finland.

Table 5: Recent regulations of maternity/paternity leave within other old member states except founder states of the European Union

\begin{tabular}{|c|c|c|c|c|}
\hline No. & Country & Latest regulations & EU accession & Latest regulations \\
\hline 1. & Denmark & & 1973 & 2013 \\
\hline 2. & Ireland & & 1973 & 2005 \\
\hline 3. & United Kingdom & & 1973 & 1992 \\
\hline 4. & Greece & & 1981 & 2000 \\
\hline 5. & Portugal & & 1986 & 2009 \\
\hline 6. & Spain & & 1986 & 2009 \\
\hline 7. & Austria & 1967 & 1995 & \\
\hline 8. & Finland & & 1995 & 2004 \\
\hline 9. & Sweden & & 1995 & 2010 \\
\hline
\end{tabular}

\section{Source: MISSOC data base}

Four CEE countries provide maternity/paternity leave following updated regulations adopted before their EU accession. It is the case of: Hungary and Croatia (seven years before); Lithuania (four years before), and Estonia (two years before).

Eight CEE countries changed their regulations after joining EU: Poland and Slovakia in 2004; Czech Republic and Romania (three years after); Bulgaria (seven years after); and Cyprus, Latvia, and Slovenia (nine years after). Maternity/paternity leave in Malta is governed by the Social Security Act. 
Table 6: Recent regulations of maternity/paternity leave within Central and Eastern European member states

\begin{tabular}{|c|c|c|c|c|}
\hline No. & Country & Latest regulations & EU accession & Latest regulations \\
\hline 1. & Cyprus & & 2004 & 2013 \\
\hline 2. & Czech Republic & & 2004 & 2008 \\
\hline 3. & Estonia & 2002 & 2004 & \\
\hline 4. & Hungary & 1997 & 2004 & 2013 \\
\hline 5. & Latvia & & 2004 & \\
\hline 6. & Lithuania & 2000 & 2004 & - \\
\hline 7. & Malta & - & 2004 & 2004 \\
\hline 8. & Poland & & 2004 & 2004 \\
\hline 9. & Slovakia & & 2004 & 2014 \\
\hline 10. & Slovenia & & 2004 & 2010 \\
\hline 11. & Bulgaria & & 2007 & \\
\hline 12. & Romania & & 2007 & \\
\hline 13. & Croatia & & 2013 & \\
\hline
\end{tabular}

Source: MISSOC data base

\section{Applicable Statutory Basis for Maternity/Paternity Leave}

Depending on the national legislative frameworks, maternity/paternity leave is governed by various normative types such as: acts, codes, laws, emergency ordinances, and decrees. No common trend was identified in EU-28 analysed countries.

Still, dedicated normative acts on the subject of maternity/paternity are in force in 14 member stats. The detailed picture is as follows: three EU founder states (Belgium, Italy, and The Netherlands); four other old member states (Denmark, Finland, Portugal, and Sweden); and seven CEE member states (Croatia, Latvia, Lithuania, Poland, Romania, Slovakia, and Slovenia). Laws on protecting working mothers were adopted in Germany and in Italy.

Maternity/paternity leave is also regulated under complementary legislative acts under various subjects such as:

- health care (Belgium, Czech Republic, Denmark, Estonia, Finland, Hungary, Ireland, Italy, Latvia, Lithuania, Poland, Slovakia, Slovenia, and The Netherlands);

- social insurance (Austria, Bulgaria, Cyprus, Czech Republic, Greece, Latvia, Lithuania, Poland, Slovakia, and Sweden);

- labour (Belgium, Bulgaria, Denmark, France, Malta, Portugal, Slovakia, Slovenia, Spain, and The Netherlands);

- social security (France, Germany, Luxembourg, Malta, Spain, and United Kingdom);

- equal treatment between men and women (Italy and Spain);

- family (Austria);

- social welfare (Hungary);

- child (Romania).

\section{Basic Principles of Providing Maternity/Paternity Leave}

The main principle in providing benefits in kind and cash benefits related to maternity leave is the affiliation to compulsory social insurance scheme. In Denmark it is in-force the universal public health service for benefits in kind, and universal protection scheme for cash benefits. A similar situation is in Finland. Voluntary insurances are available for selfemployed persons in Bulgaria, in Czech Republic, and in Slovakia. In The Netherlands not insured self-employed can apply for cash benefits. In Finland, Portugal, Spain, and United Kingdom special cash benefits are available for parents who do not satisfy the minimum conditions for ordinary maternity/paternity support.

Residency criteria is specifically mentioned in Bulgaria, France, Ireland, Italy, Latvia, Malta, Poland, Portugal, Slovakia, Sweden, The Netherlands, and United Kingdom. A further research on eligibility criteria for being socially insured in other EU member states than above mentioned ones would probably support the idea of residency for more countries than the ones explicitly referring to it. In The Netherlands working non-residents are entitled for benefits in kind. 
Unauthorised foreigners in Spain are entitled to receive health care during pregnancy, birth and postpartum.

Other expressions used when referring to potential beneficiaries of maternity//paternity leave are:

- all inhabitants (Denmark, Finland, Ireland, Italy, Latvia, Portugal, and Romania);

- members of the family (Belgium and Spain);

- active population and assimilated groups (Poland and Spain);

- national (Bulgaria);

- certain categories of citizens (Cyprus);

- female dependants (Greece);

- various other groups (Hungary);

- employees and assimilated (Italy);

- spouses of residents (Malta).

Profession related insurance approach for maternity/paternity leave is applicable in one EU founder (France), and two CEE member states (Lithuania and Slovakia). In the case of benefits in kind in France the difference is made between compulsory social insurance scheme with affiliation based firstly on professional criteria and secondly based on residency. Similarly, special schemes applies for certain professional categories in Lithuania (officers of the police, state security, defence and related services financed by the state), and in Slovakia (for policemen, soldiers, and customs officers).

\section{Benefits in Kind Related to Maternity/Paternity Leave}

Half of the EU member states do not request any qualifying condition. It is the case of three EU founder states (Germany, Luxembourg, and The Netherlands); three other old member states (Austria, Finland, and Spain); and eight CEE countries (Croatia, Czech Republic, Estonia, Hungary, Latvia, Poland, Romania, and Slovenia).

Frequent eligibility criteria for benefits in kind are: residence (Cyprus, Denmark, Ireland, Portugal, Slovakia Sweden, and United Kingdom); previous contribution to insurance scheme (Belgium, France, Greece, and Malta); working status (Sweden). In Cyprus citizenship as eligibility criteria is not applicable for beneficiaries of public assistance. In Italy the beneficiary should be registered at the National Health Service.

Various forms of benefits in kind are offered in analysed EU-28 member states. They include free medical services/midwife care during the pregnancy, birth, and postpartum; pharmaceutical products; or forms of exemption or reimbursements of payments of various patients' fees and contributions. Monitoring and assistance during labour, and delivery at home are provided in Belgium. In slightly different conditions due to recent changes they are also available in Hungary. Home care is offered in Germany. In Slovenia includes two visits of the nurse. In Greece childbirth benefit is provided for women giving birth out of hospital facilities (for example at home). Different amounts are supported for hospitalisation in private clinics in Greece depending on their contracts with the National Health System. A maternity package with necessities for child care (or its 140 euro equivalent) is offered in Finland.

\section{Cash Benefits Related to Maternity/Paternity Leave}

Six EU member states do not request any qualifying conditions: two EU founder (Italy and The Netherlands); one other old member state (Austria); and three CEE countries (Latvia, Poland, and Malta).

The most frequent condition for receiving cash benefits is the previous contributions to insurance scheme (Belgium, Bulgaria, Croatia, Cyprus, Denmark, France, Greece, Hungary, Ireland, Lithuania, Portugal, Romania, Slovenia, and Sweden). The insured period vary between 26 weeks (Cyprus); to six months (Belgium, Luxembourg, and Portugal), 240 days (Sweden); 270 days in the last two years (Czech Republic and Slovakia); and 12 months (Bulgaria, Croatia, and Lithuania).

Insurances contributions with interruptions are accepted in Croatia (18 months during last two years); in Denmark (120 hours worked in previous 13 weeks); in Greece (200 days during last two years); in Ireland (39 contributions paid or credited one year before for employees and 52 contributions within last, second last or third last year for self-employed); in Lithuania (12 months insurance during past 24 months); in Romania (1 month in the last 12 months); and in Spain (180 contributions in the previous seven years before birth or 360 contributions days in the whole working life).

Other eligibility conditions include: working status (Estonia); and determined period of previous residency (Finland). No minimum working contribution is required in Spain in the case of workers under 21 years.

Other eligible categories of beneficiaries include unemployed entitled to unemployment insurance, persons 
finalising a vocational course within previous 18 months, beneficiaries of activation measures on the labour market, students in paid internship, or people in a flexible job. A ten days benefit is paid in Sweden for parents who refrain from work in connection wit the death of their child under 18 years child.

\section{Duration of Maternity/Paternity Leave}

Analyse includes two dimensions: before and after birth periods, and support measures allocated by gender.

By categories of EU member states, the EU founder states is the most stable category providing similar pre-natal and post-natal coverage of maternity/paternity leave. The following category is represented by CEE member states.

All EU founder states provide pre natal and post-natal maternity leave. None of them provides pre-natal paternity leave. Post-natal paternity leave is provided in all six countries except Germany.

As for the category other old member states than EU founders, pre-natal maternity leave is regulated except Spain. Pre-natal paternity leave is not provided while the post-natal one is provided in five countries: Denmark, Spain, Portugal, Finland, and United Kingdom.

Pre-natal and post-natal maternity leave are regulated in all CEE member states. Estonia is the only EU country providing pre-natal paternity leave which optionally could be taken after the birth. Post-natal paternity leave is provided in nine CEE states.

Table 7: Provision of maternity/paternity leave in EU-28 member states

\begin{tabular}{|l|c|c|c|}
\hline & EU founder states & Other old member states & CEE member states \\
\hline Pre-natal maternity leave & $\begin{array}{c}\mathrm{BE}, \mathrm{DE}, \mathrm{FR}, \mathrm{IT}, \mathrm{LU}, \\
\mathrm{NL}\end{array}$ & $\begin{array}{c}\mathrm{DK}, \mathrm{IE}, \mathrm{EL}, \mathrm{AT}, \mathrm{PT}, \mathrm{FI}, \mathrm{SW}, \\
\mathrm{UK}\end{array}$ & $\begin{array}{c}\text { BG, CZ, ET, HR, CY, LV, LT, HU, MT, PL, RO, } \\
\text { SI, SK }\end{array}$ \\
\hline Pre-natal paternity leave & - & - & $\mathrm{ET}$ \\
\hline Post-natal maternity leave & $\begin{array}{c}\mathrm{BE}, \mathrm{DE}, \mathrm{FR}, \mathrm{IT}, \mathrm{LU}, \mathrm{NL} \\
\mathrm{NL}\end{array}$ & $\begin{array}{c}\mathrm{DK}, \mathrm{IE}, \mathrm{EL}, \mathrm{ES}, \mathrm{AT}, \mathrm{PT}, \mathrm{FI}, \\
\mathrm{SW}, \mathrm{UK}\end{array}$ & $\begin{array}{c}\mathrm{BG}, \mathrm{CZ}, \mathrm{ET}, \mathrm{HR}, \mathrm{CY}, \mathrm{LV}, \mathrm{LT}, \mathrm{HU}, \mathrm{MT}, \mathrm{PL}, \mathrm{RO}, \\
\mathrm{SI}, \mathrm{SK}\end{array}$ \\
\hline Post-natal paternity leave & $\mathrm{BE}, \mathrm{FR}, \mathrm{IT}, \mathrm{LU}, \mathrm{NL}$ & $\mathrm{DK}, \mathrm{ES}, \mathrm{PT}, \mathrm{FI}, \mathrm{UK}$ & $\mathrm{BG}, \mathrm{ET}, \mathrm{LV}, \mathrm{LT}, \mathrm{HU}, \mathrm{MT}, \mathrm{PL}, \mathrm{RO}, \mathrm{SI}$ \\
\hline
\end{tabular}

Source: Author's calculations based on MISSOC data base

Two cases of before birth maternity leave were identified: either a precise period of time is mentioned, either a total amount of time to be split between pre-natal and post-natal periods. Countries from the first category are: Belgium, Croatia, Denmark, France, Germany, Lithuania, Luxembourg, Romania, Slovakia, Spain, and Sweden. The second category includes: Austria, Bulgaria, Cyprus, Czech Republic, Estonia, Finland, Greece, Hungary, Ireland, Italy, Latvia, Malta, Poland, Portugal, Slovenia, The Netherlands, and United Kingdom. Some countries from the first category offer the possibility to add the remaining pre-natal maternity leave to the post-natal one. It is the case of Belgium, France, Germany, and Romania. A further research on this particular aspect would support a better understanding of pre-natal common trends in EU-28.

Table 8: Provision of pre-natal maternity leave by regulated amount of time

\begin{tabular}{|l|c|c|c|}
\hline & EU founder states & Other old member states & Central and Eastern member states \\
\hline Fixed & $\mathrm{BE}, \mathrm{FR}, \mathrm{DE}, \mathrm{LU}$ & $\mathrm{DK}, \mathrm{ES}, \mathrm{SW}$ & $\mathrm{HR}, \mathrm{LT}, \mathrm{RO}, \mathrm{SK}$ \\
\hline Flexible & $\mathrm{IT}, \mathrm{NL}$ & $\mathrm{AT}, \mathrm{PT}, \mathrm{Fl}, \mathrm{ES}, \mathrm{IE}, \mathrm{UK}$ & $\mathrm{BG}, \mathrm{CY}, \mathrm{CZ}, \mathrm{ET}, \mathrm{HU}, \mathrm{LV}, \mathrm{MT}, \mathrm{PL}, \mathrm{SI}$ \\
\hline
\end{tabular}

Source: Author's calculations based on MISSOC data base

Maternity leave in analysed EU-28 member states include different periods of time as follows:

- $\quad$ eight weeks (Austria);

- 14 weeks (Belgium, Germany, Malta, and Sweden);

- 15 weeks (Finland and Slovenia);

- 16 weeks (France, Latvia, Luxembourg, Spain, and The Netherlands);

- 17 weeks (Greece);

- 18 weeks (Cyprus, Denmark, Lithuania, and Romania); 
- 20 weeks (Estonia and Poland);

- 24 weeks (Hungary);

- 26 weeks (Ireland);

- 28 weeks (Czech Republic);

- 34 weeks (Slovakia);

- 52 weeks (United Kingdom);

- 120 or 150 days (Portugal);

- five months (Italy);

- seven months (Croatia);

- 420 days (Bulgaria).

The compulsory maternity leave period is mentioned rather after the birth than before the birth. Still, compulsory pre-natal leave varies between minimum one week in Belgium and a maximum of four weeks in The Netherlands. Regardless the two above mentioned category of time regulation, other recommended period of pre-natal leave are:

- two weeks (Ireland);

- four weeks (Denmark, Estonia, Hungary, Italy, Portugal, Slovenia, and The Netherlands);

- five weeks (Malta);

- six weeks (Belgium, Bulgaria France, and Germany);

- seven weeks (Sweden);

- 56 days (Greece and Latvia)

- 30-50 days (Finland);

- 63 days (Romania)

- Between the $9^{\text {th }}$ and $2^{\text {nd }}$ weeks (Cyprus);

- Six to eight weeks (Czech Republic, Poland, and Slovakia);

- 11 weeks (United Kingdom);

- 70 days (Lithuania).

Special cases (multiple births, complication, premature, hospitalisation, and Caesarean) implies additional period of leave in Austria, Belgium, Croatia, Czech Republic, France, Germany, Poland, Latvia, Lithuania, and in Spain. Benefits for risk during pregnancy are provided in Portugal and in Spain.

When regulated, the compulsory post-natal maternity leave could include: four weeks (Ireland); six weeks (Czech Republic, Romania); or nine weeks (Belgium). For more details please consult Annex 1: Duration of maternity/paternity leave in EU-28 ember states.

The only country mentioning conditions for paternity leave is Estonia where ten days can be taken either before or after the delivery. The minimum numbers of days for post-natal paternity leave is one compulsory day in Italy while the maximum is 54 days in Finland. Other allocated amounts of time are:

- two days (Luxembourg, Malta, and the Netherlands);

- five days (in Hungary and Romania);

- One or two weeks (United Kingdom);

- ten days (Belgium, Estonia, Latvia, and Portugal);

- 11 days (France);

- 14 days (Denmark and Poland);

- 15 days (Bulgaria and Slovenia);

- 18 days (in France in the case of multiple births);

- four weeks (Lithuania and Spain);

- 54 days (Finland).

Additional days for paternity leave are available: two days in Italy; ten days in both Romania (if the father graduates an infant care course) and Portugal; and 75 days in Slovenia.

No post-natal paternity leave is regulated in Austria, Croatia, Cyprus, Czech Republic, Germany, Greece, Ireland, Slovakia, and Sweden. Still, in some of these countries fathers are supported by other means. In Croatia, the father can continue the maternity leave but only after 70 days after birth. In Ireland some employers provide paid leave even if it is not compulsory in the country. Reduced working hours are available in Greece for parents after an additional special maternity leave (which follows the ordinary maternity leave and can be up to six months).

Some countries support the involvement of both mothers and fathers in the child care during first months. Two 
sets of measures were identified: either by the possibility to transfer the remained time from not used maternity leave to the father; either by common parental leave (32 weeks in Denmark before the $9^{\text {th }}$ birthday of the child, 158 days in Finland, and three months in Portugal). The Slovenian father can take 75 days unpaid leave till the third anniversary of the child. The Romanian father should take one month out of the 12 child raising leave which follows the maternity leave.

Difference between employed and self-employed people when touching maternity benefits is made in both Belgium and France. Special maternity allowance is offered for Finish mothers if the working environment exposed them to chemical substances, radiation, or to an infectious disease. Austrian post-natal maternity leave is provided for the duration of an individual employment prohibition. Reduced working hours for parents are regulated in Denmark, in Greece, and in Sweden. A benefit for risk is paid for Spanish breastfeeding working mothers till child reaches nine months of age.

The Finish maternity/paternity leave includes consecutive calendar days except Sundays. Calendar days are also mentioned in Latvia and in Lithuania.

Portuguese grandparents are entitled to substitute parents in leave if special conditions are accomplished (i. g. living in the same household or parents less than 16 years).

Adoption maternity/paternity leave is regulated in $21 \mathrm{EU}$ member states as follows: five EU founders (Belgium, France, Italy, Luxembourg, and the Netherlands); eight other old member states (Denmark, Finland, Greece, Ireland, Poland, Portugal, Spain, and United Kingdom); and eight CEE countries (Bulgaria, Croatia, Cyprus, Czech Republic, Estonia, Hungary, Slovakia, and Slovenia).

Regarding continued payment of maternity/paternity leave by the employer, no statutory continuation is regulated in 21 EU member states: half of EU founder states ( (Belgium, Luxembourg, and The Netherlands); seven other old member states (Austria, Denmark, Finland, Ireland, Portugal, Spain, and Sweden), and 12 CEE countries (except Malta).

Employer is involved in the payment for differences in the case of poor employees (Austria); or for the differences between maternity benefits and salary (France and Germany). Payments are also supported by the employer in line with additional conditions included in collective agreements (Cyprus and Spain). Certain periods of time are supported by employers from Belgium (first three days of the paternity/adoption leave); from Greece (15 days/one months depending of number of completed worked days); and from Malta (14 weeks of maternity leave, and two days of paternity leave).

\section{Conclusions}

First part of the paper overviews demographic trends in EU-28. Eurostat 1960-2012 data showed a decreased number of births and an increased number of deaths. As shown in figure 1, EU-28 births in 2012 scored the lowest value since 2006 while the number of death was the second higher one since 1960.

Demographic drivers conducted to population growth in 17 member states: all EU founder states, six other old member states than EU founders, and five CEE countries. No growth only to natural change was registered in EU founder states. No population decline due only to or more to natural change was recorded in the category of other old member states than EU founders.

1960-2012 fertility rates showed different patterns within the three categories of member states. Top position as highest fertility rates within other old member states was occupied by Ireland (except for 1990); while The Netherlands and France shared top positions among EU founders. Six CEE countries occupied this position among which Estonia three for tree consecutive periods of time. The highest value for 1960-2012 was 3,85 registered in 1970 in Ireland, country where abortion is only allowed to save the life of the women.

The second part of the article compares provision of maternity/paternity leave in EU-28 by the three categories of EU member states. Analysed aspects were the following: national regulations, applicable statutory basis, basic principles and qualification conditions in providing benefits in kind and cash benefits, as well as the duration of maternity/paternity leave.

Updated regulations for maternity/paternity leave date since 2000 in 24 out of EU-28. Among other old member states than EU founders, Austria is the only country which still follows pre-accession adopted regulation. The same applies for four CEE member states: Estonia, Hungary, Lithuania, and Croatia.

From the applicable statutory basis, special legislative acts on maternity/paternity leave were adopted in 14 member states: three EU founder states, four other old member states, and seven CEE countries. Complementary regulations with impact on maternity/paternity leave refers to various issues such as health care, social insurance, labour, social security, equal treatment between men and women, family, social welfare, and child.

Main basic principle in providing benefits in kind and cash benefits related to maternity/paternity leave is the affiliation to compulsory social insurance scheme. Some countries accept contributory periods with interruptions. 
Half of EU-28 member states do not request qualifying conditions for providing benefits in kind. Still, eligibility criteria include residence, previous contribution to insurance scheme, or working status. Six EU member states don't request qualifying conditions for cash benefits. Still, the most frequent condition is previous contribution to insurance scheme.

Duration of maternity/paternity leave was analysed as pre-natal and post-natal regulated for both mothers and fathers. Per category of EU member states, CEE counties covered all four types of leave (pre-natal and post-natal leave for both men and women).

Two cases of before birth maternity leave were identified: either a precise period of time is mentioned, either a total amount of time to be split between pre-natal and post-natal periods. Detailed analyse for each category are included in the article.

21 EU member states regulate adoption maternity/paternity leave as follows: five EU founders (except Germany); eight other old member states (expect Austria); and eight CEE countries (except Latvia, Lithuania, Malta, Poland, and Romania).

Continued payment of maternity/paternity leave is not regulated in 21 member states. In other states, the employer is involved in the payment related to income differences or to regulated periods of time.

Research on maternity/paternity leave will be continued with analyse of complementary family benefits. Few questions arise. To what extend are the current maternity/paternity leave related regulations suitable in the child delivery and care process? Which elements are to be further adjusted? Are the parents really supported in the process of having and raising a child? Can parents go back to work having small children at home?

Despite common interest for family within current demographic trends, the design of family support policies is to be further tackled and, in this respect, one of first steps is a better harmonisation of maternity/paternity leave among EU-28.

Home-work struggle for balance and population change call for a friendly approach of designed social policy measures. One cannot dream about sustainable demographic scenario without paying proper attention to efficiency of child delivery and care process.

\section{Acknowledgement}

This paper has been written and published under the aegis of the Research Institute for Quality of Life, Romanian Academy as part of the postdoctoral research programme co-funded by the European Union within the Sectorial Operational Programme for Human Resources Development through the project "Pluridisciplinarity and interdisciplinarity in doctoral and post-doctoral programmes" Project Code: POSDRU/159/1. 5/S/141086.

\section{References}

Balan, M. ; Vasile, V. ; Stanescu, S. M. ; 2013. Gravity model application to estimate Romanian migration size, Knowledge horizons, volume 5, no. 2/2013, 74-78 http: //www. orizonturi. ucdc. ro/arhiva/2013_khe_2_pdf/khe_vol_5_iss_2_74to78. pdf

Balan, M. ; Stanescu, S. M. ; 2014. Unemployment Impact on Families in Developmennt Regions of Romania, in Constantinueanu, C. ; Runcan, P. ; Runcan, R. (editors) Authority \& Power of Christian Values, Bucuresti, Editura Didactica si Pedagogica, 11-18

Cerami, A. ; Stanescu, S. M. ; 2009. Welfare State Transformation in Bulgaria and Romania, in Cerami, A. ; Vanhuysse, P. (editors) Post-Communist Welfare Pathways Theorizing Social Policy Transformations in Central and Eastern Europe, Palgrave, Macmillan, 112-126

Cojocaru, S. 2009. Child rights based analysis of children without parental care or at risk of losing parental care in Romania. Revista de cercetare si interventie socială, $24,41-71$

Esping-Andersen, G. 2009, Incomplete Revolution: Adapting Welfare States to Women's New Roles, Cambridge, Polity Press

Ghetau, V. 2012. Drama noastra deografica Populatia Romaniei la recensamantul din octombrie 2011. Bucuresti, Compania

Kvist, J. , Saari, J. , 2007. The Europenisation of social protection: domestic impacts and national responses in Kvist, J. , Saari, J. (editos), The Europeanisation of social protection, The Policy Press, 229-248

Kuronen, M. 2010, Research on Families and Family policies in Europe State of the Art, Commission of the European Communities Research Directorate-General http: //www. mmmeurope. org/ficdoc/FAMILYPLATFORM-Final-Report-04-2011. pdf

Luca, C. 2014. Expertiza psihologica a copilului abuzat/neglijat, Hamangiu, lasi

Mihalache, F. 2011. Calitatea vietii comunitare, in Marginean, I. ; Precupetu, I. (editors). Paradigma calitatii vietii, Bucuresti, Editura Academiei Romana, 131-140

Muresan, C. 2014. Postponement of Motherhood in Romania: The Role of Educational Attainment. Revista de Cercetare si Interventie Sociala, 47, 137-149

Neamtu, N. 2007. Succes si esec in plasamanetul familial, in contextul reformei sistemului de protectie a copilului din Romania, ClujNapoca, Accent 
Pânzaru, C. , Tomită, M. 2013. Parent Involvement and Early School Leaving. Revista de Cercetare si Interventie Sociala,40, 21-36

Popescu, R. ; 2009. Introducere in sociologia familiei Familia romaneasca in societatea contemporana, Iasi, Polirom

Rotaru, T. , 2009, Demografia si sociologia populatiei, Iasi, Polirom

Stănescu, I. 2014. Romania: a non-interventionist family support policies? Mediterranean Journal of Social Sciences, vol. 5, no. 19, august 2014, pp. 778-783

Stănescu,, S. M. ; 2006, Modelul social european, in Zamfir, C. ; Stoica, L. (coordonatori), O nouă provocare: dezvoltarea socială, Polirom, laşi, 2006

Stănescu, S. M. 2013, Statul bunăstării între supravieţuire, reformă şi integrare europeană, Bucureşti, ProUniversitaria

Stănescu, S. M. 2014. The impact of the EU Accession of ast European countries on their institutional shape of social policy în volumul ПАРТНЕРСТВО ВО ИМЯ БЛАГОПОЛУЧИЯ, Partnership for the Welfare, Belarus, 183-197

Stănescu, S. M. ; Nemtanu, M. ; 2015. Family benefits in member states of the European Union: a comparative perspective (in print)

Tomita, M. 2014. Developing Alternative Understandings of Conflicts That Involve Delinquent Children through Life Space Crises Intervention. Revista de Cercetare si Interventie Sociala, 44, 67-85

Turliuc, M. , N. ; Marici, M. , 2013, What do Romanians Parents and Adolescents Have Conflicts about?, Revista de Cercetare şi Intervenţie socială, vol. 42/ september 2013, pp. 28-49

Vaughan-Whitehead, D. , 2004. EU Enlargement versus Social Europe?, The Uncertain Future of the European Social Model, Edward Elgar Publishing Limited, USA

Vlase, I. 2014. L'impact de la crise sur la vie des chômeurs, Revista Calitatea Vietii, XXV, nr. 3/2014, 235-258

Vonica Răduţiu, S. , (editor), Băjenaru, C. , Doboş, C. , Niţulescu, D. C. , Popescu, R. , Stoica, L. , 2004. Aderarea României la Uniunea Europeană: impactul asupra statului bunăstării românesc, Academia Română, nr. 122-123,

Uzlau, C, Nicolae-Balan, M. ; Radu, B. M. 2009, Tendinte pe plan mondial in domeniul public de sanatate, in Albu, L. ; Nicolae-Balan, M. (editors) Sistemul public de sanatate si cresterea economica, Bucuresti, Expert, 15-93

Annex 1: Duration of maternity/paternity leave in EU-28 ember states

\begin{tabular}{|c|c|c|c|c|}
\hline \multirow[t]{2}{*}{ Country } & \multicolumn{2}{|l|}{ Before birth } & \multicolumn{2}{|l|}{ After birth } \\
\hline & Maternity & Paternity & Maternity & Paternity \\
\hline Austria & 8 weeks (before + after) & & $\begin{array}{l}8 \text { weeks /12 (premature, multiple birth or } \\
\text { Caesarean) }\end{array}$ & \\
\hline Belgium & 6 weeks (1 compulsory)/8 (multiple births) & & 9 mandatory weeks (+remained prenatal) & 10 days \\
\hline Bulgaria & 410 days ( 45 before + after) & & 410 days (before + after) & 15 days $^{4}$ \\
\hline Croatia & 28 days/45 days (complications) & & 6 months $^{5}$ & \\
\hline Cyprus & 18 weeks $^{6}$ (before + after) & & 18 weeks $^{7}$ & \\
\hline $\begin{array}{l}\text { Czech } \\
\text { Republic }\end{array}$ & 28 weeks $^{8} / 37$ days (multiple births) & & 28 weeks $^{9} / 37$ weeks (multiple births) & \\
\hline \multirow[t]{2}{*}{ Denmark } & \multirow[t]{2}{*}{4 weeks } & & 14 weeks & 2 weeks $^{10}$ \\
\hline & & & \multicolumn{2}{|l|}{32 weeks before the 9th birthday of the child } \\
\hline Estonia & 140 (before 30 days + after) & 10 days $^{11}$ & 140 days (before + after) & 10 days \\
\hline \multirow[t]{2}{*}{ Finland } & \multirow[t]{2}{*}{105 days (before $30-50$ days + after) } & & 105 day (55-75 days after) & 54 days $^{12}$ \\
\hline & & & \multicolumn{2}{|l|}{158 days $^{13}$} \\
\hline \multirow[t]{3}{*}{ France } & 6 weeks +2 (pathological pregnancy) & & 10 weeks & \multirow{3}{*}{$\begin{array}{l}11 \text { days }{ }^{14} \\
18 \text { days (multiple births) }\end{array}$} \\
\hline & 8 weeks (the $3^{\text {rd }}$ child) & & \multirow[t]{2}{*}{18 weeks ( $3^{\text {rd }}$ child $)$} & \\
\hline & 12 weeks (twins) 24 (multiple births) & & & \\
\hline Germany & 6 weeks/12 (premature, multiple) & & 8 weeks & \\
\hline Greece & 119 days ( 56 before +63 after) & & 119 days & \\
\hline Hungary & 24 weeks (4 optional before) & & 24 weeks & 5 days \\
\hline Ireland & 26 weeks (at least two before) & & 26 weeks (at least four after) & \\
\hline Italy & 5 months (1or 2 before + after) & & 5 months (before + 3 to 4 months) & 1 compulsory day ${ }^{15}+2$ days $^{16}$ \\
\hline
\end{tabular}

${ }^{4}$ For eligible at least 12 months of insurance fathers

5 Including 70 compulsory days after which father can continue

${ }^{6}$ Beginning the $9^{\text {th }}$ to $2^{\text {nd }}$ weeks before expected birth

${ }^{7}$ An extension of maximum six weeks for hospitalized child

${ }^{8}$ Beginning the $8^{\text {th }}$ to $6^{\text {th }}$ weeks before expected birth

${ }_{9}^{9}$ Shorter 14 weeks leave in total including six weeks after if the child dies

10 Continuous weeks within the 14 weeks after birth

11 Within the period of two months before the estimated date of confinement or two months after the birth of a child.

${ }^{12}$ Excluding Sundays. The father can take 1-18 days as paternity leave after the child is born during the maternity and parental leave.

${ }_{13}$ Parental leave excluding Sundays. In case of multiple births 60 days are added for each additional child.

14 Within the four months after the birth

${ }_{15}$ To be claimed within five months after the child's birth

16 In replacement of maternity paid leave 


\begin{tabular}{|c|c|c|c|c|}
\hline \multirow[t]{2}{*}{ Country } & \multicolumn{2}{|l|}{ Before birth } & \multicolumn{2}{|l|}{ After birth } \\
\hline & Maternity & Paternity & Maternity & Paternity \\
\hline Latvia & 112 days $(56 \text { before }+ \text { after) })^{17}$ & & 112 days (before +56 days after) & 10 calendar days \\
\hline \begin{tabular}{|l} 
Lithuania \\
\end{tabular} & 70 calendar days & & 56 days $^{18}$ & 1 month \\
\hline Luxembourg & 8 weeks & & 8 weeks $^{19}$ & 2 days \\
\hline Malta & $\begin{array}{l}14 \text { weeks (maximum } 9 \text { weeks before + } \\
\text { after) }\end{array}$ & & \begin{tabular}{|l|} 
At least 5 weeks \\
4 weeks (an additional paid maternity leave \\
benefit)
\end{tabular} & 2 days \\
\hline Poland & 20 weeks ( 6 before /8 for hospitalisation) & & \begin{tabular}{|l|}
20 weeks $^{20}$ \\
6 weeks/8 (multiple) (an additional maternity \\
leave)
\end{tabular} & 2 weeks $^{21}$ \\
\hline Portugal & 30 days $^{22}$ & & \begin{tabular}{|l}
6 weeks compulsory \\
3 months (extended parental leave)
\end{tabular} & 10 days $^{23}+10$ days $^{24}$ \\
\hline Romania & 63 days $^{25}$ & & 63 days (42 compulsory) & 5 days +10 days $^{26}$ \\
\hline Slovakia & 6 - 8 weeks & & $\begin{array}{l}4 \text { weeks }^{27} / 37 \text { (single mothers)/43 (multiple } \\
\text { births) }\end{array}$ & \\
\hline Slovenia & 105 days ( 28 days before + after) & & 105 days (before +77 after) & 15 days ${ }^{28}+75$ days s $^{29}$ \\
\hline Spain & & & 16 weeks $^{30}$ & 4 weeks \\
\hline Sweden & 7 weeks & & 7 weeks & \\
\hline \begin{tabular}{|l} 
The \\
Netherlands
\end{tabular} & 16 weeks (compulsory 4 to 6 before ) & & 16 weeks (10 to 12$)$ & 2 days \\
\hline \begin{tabular}{|l|} 
United \\
Kingdom
\end{tabular} & 52 weeks (since $11^{\text {th }}$ before and after) & & 52 weeks (before and after) & 1 or 2 weeks ${ }^{31}$ \\
\hline
\end{tabular}

Source: MISSOC data base, $1^{\text {st }}$ of January 2014

1714 additional days of leave and benefit for women who have received continuous medical care commencing before the 12 th week of pregnancy. Further 14 days are available for complications during pregnancy, delivery or post-natal period and for multiple births.

${ }^{18}$ In cases of complicated deliveries or multiple birth, benefits are payable for 70 days after delivery. In case of premature childbirth (more than 22 weeks of pregnancy) benefits are paid for 28 days after delivery (if the child survives: for 120 days).

19 Supplement of four weeks for nursing mothers and in case of premature birth or multiple births.

20 Minus pre-natal weeks and varies to 31 weeks (twins), 33 weeks (triplets), 35 weeks (quadruplets), 37 weeks (quintuplets or more)

${ }^{21}$ To be taken until the child is 12 months of age.

22 Part of initial parental leave 120 or 150 consecutive days

${ }^{23}$ Of which five days must be taken consecutively immediately after birth and five days during the subsequent 30 days

${ }^{24}$ Consecutive or not but to be taken during the initial parental leave of the mother

${ }_{25}$ Periods may be compensated between according to medical advice and the option of the beneficiary, provided the period after confinement is longer than 42 days.

${ }^{26}$ Additional ten days if father graduates a child-care course

27 If the child dies, the total duration is shorter, but not less than 14 weeks and cannot be terminated in the six weeks following the delivery

${ }^{28}$ During the first six months of the child's life

${ }^{29}$ To be used until the child's 3rd birthday, during which the state pays social security contributions for the father.

30 Two extra weeks per child as from the second child in case of multiple birth; and birth, of a disabled child. If both parents work, ten weeks may be granted to the father.

${ }^{31}$ Can be taken within 56 days of the date of birth, or if the child is born early, within the period from the actual date of birth up to 56 days after the first day of the week in which the birth was expected. 